(C) 2016. This manuscript version is made available under the CC-BY-NC-ND 4.0 license http://creativecommons.org/licenses/by-nc-nd/4.0/

\title{
Combined effects of ozone and freeze-drying on the shelf-life of Broiler chicken meat
}

\author{
María J. Cantalejo, Ferdaous Zouaghi, Iratxe Pérez-Arnedo \\ LWT - Food Science and Technology, Volume 68, May 2016, Pages \\ 400-407 \\ DOI: http://dx.doi.org/10.1016/j.lwt.2015.12.058
}




\section{Combined effects of ozone and freeze-drying on the shelf-life of Broiler chicken meat}

\section{Introduction}

Chicken meat is one of the most popular food commodities in Europe and the second most preferred meat by European Union consumers after pork meat (FAO, 2014). Some of the reasons for the popularity of this kind of meat are the relatively low price, low fat content and the high nutritional value. Generally, poultry meats are highly perishable to bacterial contaminants due to large amounts of variable nutrients, a high water activity $\left(\mathrm{a}_{\mathrm{w}}\right)$ and a higher final $\mathrm{pH}$ limiting the shelf-life of the product (Lawrie, 1998). In the case of meat and meat products, enzymatic and chemical reactions are responsible for the initial loss of freshness, while microbial activity is responsible for subsequent spoilage. The contamination by several pathogenic microorganisms can cause severe foodborne diseases in consumers (Jayasena et al., 2015).

However, the manufacturing of meat products is constantly challenged to meet rapid changes in consumer tastes and demands for healthier food products, safe, natural, free of conventional chemical preservatives with an extended shelf-life. Consumer acceptance is the key success factor for the development of successful meat products (De Barcellos et al., 2010) and meat safety is considered to be a prerequisite by consumers (Van Wezemael, Verbeke, Kügler, de Barcellos, \& Grunert, 2010). For this purpose, the multiple hurdle concept is an integrated basic approach in food preservation and the hurdle technology is generally defined as using the simultaneous or the sequential application of factors and/or treatments affecting microbial growth (Turantaş, Kılıç, \& Kılıç, 2015). The principle of this concept can be explained as two or more inhibition and inactivation methods (hurdles) at suboptimal levels are more effective than one (Leistner, 1992). This method is becoming attractive, because several hurdles are used to obtain the optimum combinations which do not affect the sensory quality, while maintaining the microbial stability and safety of the food (Alzamora, Tapia, Argaíz, \& Welli, 1993; Leistner, 1992). In fact, ozonation and freeze-drying were employed as hurdles in the present study to develop a new raw meat product from Broiler chicken breasts. Ozone is a powerful antimicrobial agent very effective in destroying a wide range of microorganisms including viruses, bacteria, fungi, protozoa, 
and bacterial and fungal spores (Khadre \& Yousef, 2001). This agent inactivates bacteria by disrupting the cell membrane and cell wall, leading to cell lysis (Muhlisin, Cho, Choi, Hahn, \& Lee, 2015). Ozone is used in an extensive range of agricultural products, such as vegetables, fruits, fish (Manousaridis et al., 2005) and meat products (Muhlisin et al., 2015; Sekhon et al., 2010; Stivarius, Pohlman, McElyea, \& Apple, 2002). The bactericidal effect of ozone depends on several factors, such as temperature, relative humidity, $\mathrm{pH}$ and the presence of organic matter (Kim, Yousef, \& Chism, 1999).

Freeze-drying is the most common form of food preservation to improve the longterm stability of food because the percentage of humidity and the water activity can be reduced, if the product is well lyophilized, which retards the growth of microorganisms for a long period. This process applies only for high added-value products (Abdelwahed, Degobert, Stainmesse, \& Fessi, 2006). Freeze-drying has many applications on food products, such as chicken meat, raw beef, mushrooms, fruits, carrots, tomato, eggs, etc. (Babić, Cantalejo, \& Arroqui, 2009; Chang, Lin, Chang, \& Liu, 2006; Hammami \& René, 1997; Litvin, Mannheim, \& Miltz, 1998). The many advantages of lyophilisation make it one of the technologies attracting the attention of the food industry, including: (i) the conservation of the primary physical and chemical characteristics of the product, (ii) a low residual humidity $(<10 \%)$ providing easy handling during shipping and storage of the lyophilized product and, (iii) long-term stability.

The aim of this research was to study the combined effects of ozone and lyophilisation on the shelf-life extension of Broiler chicken meat fillets, stored at room temperature by evaluating microbiological load and sensory characteristics, in order to develop new high-quality raw meat products from fresh chicken meat, safe, with a high nutritional value, with no additives added and long-lasting at room temperature. Therefore, these meat products can be preserved and transported with no refrigeration, due to the relative reduction of moisture content and water activity (energy saving, as no freezing is required). Furthermore, this type of food product would allow a long shelflife in the case of natural catastrophes (earthquakes, floods,...), export to third countries, military campaigns, mountain climbers and scarcity in electricity supply. 


\section{Materials and methods}

\subsection{Raw matter and sample preparation}

Broiler chicken breast meat was obtained from U.V.E., S.A. (Tudela, Navarre, Spain). Chickens were 42 days old before slaughtering with approximately $2 \mathrm{~kg}$ of weight. All breasts were stored in a refrigerated room $\left(2-4^{\circ} \mathrm{C}\right)$ for the time of reception until used. The samples were trimmed of visible fat and nerves. They were cut into pieces (approximately $3 \times 3 \mathrm{~cm}^{2}$ of section and of $0.7 \mathrm{~cm}$ in thickness), before the analyses. Then, they were divided into three batches. The first batch was vacuumpacked, refrigerated and stored at $4 \pm 0.5{ }^{\circ} \mathrm{C}$ (P Selecta, Pharmalow, Tarre, Navarra, Spain). To characterize the fresh meat, physical-chemical measurements ( $\mathrm{pH}$, colour, water activity, humidity and texture) were performed. After characterization, the same batch was vacuum-packed, deep-frozen, and stored at $-40 \pm 1{ }^{\circ} \mathrm{C}$ (Climas, Barcelona, Spain) and used as an external reference of raw meat for sensory and microbiological analyses. The second batch of meat samples was subjected to freeze-drying only, and vacuum packed and stored in a dark place at room temperature $\left(21 \pm 1^{\circ} \mathrm{C}\right)$ and used as an internal control. The third batch of meat samples was treated with ozone, freeze-dried, vacuum-packed and stored in a dark place at $21 \pm 1^{\circ} \mathrm{C}$.

\subsection{Ozone treatments}

Ozonation assays were carried out in a $3 \mathrm{~m}^{3}$ volume refrigerated chamber (Eurozon, Ecologyc 2000, Sestao, Vizcaya, Spain) to a continuous flow of ozone gas at $4 \pm 0.5^{\circ} \mathrm{C}$ and $90 \pm 1 \%$ relative humidity. These conditions are important for the efficiency of the bactericidal effect of ozone (Kim et al., 1999). Ozone was generated in situ, utilizing a UV radiation using an ozone generator (Rilize, model 3060 Eurozon, Sestao, Spain). Ozone concentrations inside the chamber were monitored continuously by circulating air from the chamber through an ultraviolet absorption ozone gas analyzer (Ozomat MP, Anseros, Germany). The different treatments are shown in Table 4.1. Treatment combinations for this study included three ozone concentrations $(0.72,0.6$ and $0.4 \mathrm{ppm})$ and four exposure times $(120,60,30$ and $10 \mathrm{~min})$. 
Table 1. Concentrations and exposure times of gas ozone on meat samples

\begin{tabular}{lcc}
\hline \multicolumn{1}{c}{ Treatments } & $\begin{array}{c}\text { Ozone concentrations } \\
(\mathrm{ppm})\end{array}$ & $\begin{array}{c}\text { Exposure times } \\
(\mathrm{min})\end{array}$ \\
\hline (0) Trt-0 (Internal control) & - & - \\
(1) Trt-0.4/30 & 0.4 & 30 \\
(2) Trt-0.4/60 & 0.4 & 60 \\
(3) Trt-0.4/120 & 0.4 & 120 \\
(4) Trt-0.6/10 & 0.6 & 10 \\
(5) Trt-0.6/30 & 0.6 & 30 \\
(6) Trt-0.72/10 & 0.72 & 10 \\
(7) Trt-0.72/30 & 0.72 & 30 \\
\hline
\end{tabular}

\subsection{Freeze-drying process and packaging of samples}

After ozone treatments, samples were dehydrated in a pilot scale freeze-dryer (Model Lyobeta 25, Telstar Industrial, S.L., Barcelona, Spain). The different parameters of the freeze-drying process assayed in this study were the same in all treatments and were the best conditions described in the research work of Babic et al. (2009). Briefly, slow freezing, $20.5 \mathrm{~h}$ of primary drying $\left(12 \mathrm{~h}\right.$ at $0^{\circ} \mathrm{C}$ and $8.5 \mathrm{~h}$ at $\left.10^{\circ} \mathrm{C}\right)$ at $30 \mathrm{~Pa}$.

All the samples were vacuum-packed, using a vacuum packaging machine (Model SAMMIC V-640, Gipuzkoa, Spain), in impermeable plastic trays type polyamide/polyethylene PA/PE 20/70 200x300 (Ilpra, Barcelona, Spain). The doublelayer of the trays resulted in a strong and relatively impenetrable bag for both air and moisture and had an oxygen transfer rate of less than $50 \mathrm{~cm}^{3} \mathrm{~m}^{-2} \mathrm{~d}^{-1} \mathrm{bar}^{-1}$, permeability to $\mathrm{CO}_{2}$ less than $150 \mathrm{~cm}^{3} \mathrm{~m}^{-2} \mathrm{~d}^{-1} \mathrm{bar}^{-1}$ and a water vapor permeability of less than $2.8 \mathrm{~g} \mathrm{~m}^{-2}$ $\mathrm{d}^{-1}$.

Two meat controls were used in this study: (1) Lyophilized chicken samples (trt-0), that were not exposed to ozone treatment and were used as an internal control in order to analyse the efficacy of the combination of ozone and lyophilisation on the self-life of meat. (2) Frozen meat used as an external reference of raw meat (due to the similarity of those samples with the ozonated freeze-dried samples) for sensory and microbiological analyses. 


\subsection{Analyses of samples}

\subsubsection{Physical and chemical analyses}

Physical and chemical analyses $\left(\mathrm{pH}\right.$, water activity $\left(\mathrm{a}_{\mathrm{w}}\right)$, humidity, percentage of rehydration, colour and the texture) were carried out during the first day of storage for characterising the fresh meat and all treated samples.

The $\mathrm{pH}$ was measured using a pH-meter (Crison PH 25, S.A, Barcelona, Spain) with a combined electrode, which penetrates the meat samples. Water activity $\left(a_{w}\right)$ was measured by means of a hygrometer (Novasina RS-232, LabMaster, Switzerland). Humidity of fresh meat was determined in a stove (P Selecta, Digitronic, Barcelona, Spain) at $102 \pm 2{ }^{\circ} \mathrm{C}$ until constant weight, according to the ISO R-1442 regulation (ISO, 1973) and the Spanish Official Method for the Analysis of Meat Products (B.O.E., 29/8/79). Humidity of dried meat was determined following the ISO R-1442 method (AOAC, 1975), by using a gravimetric infrared stove (Gram, ST-H 50, Barcelona, Spain).

In order to know how much water was absorbed by freeze-dried chicken meat and their fully rehydration characteristics, the samples were rehydrated in trays filled with distilled water at $21-22{ }^{\circ} \mathrm{C}$. The change in mass of freeze-dried chicken meat was measured each half an hour, when all meat samples were taken out and dried with a blotting paper, then each sample was weighed. This procedure was repeated until obtaining constant weight of the samples. The percentage of rehydration was calculated using the following expression, proposed by Babić et al. (2009):

$$
\text { Rehydration }(\%)=\left(\mathrm{W}_{\mathrm{r}}-\mathrm{W}_{1}\right) /\left(\mathrm{W}_{0}-\mathrm{W}_{\mathrm{l}}\right) \times 100
$$

Where,

$\mathrm{W}_{\mathrm{r}}$ : weight of rehydrated sample $(\mathrm{g})$

$\mathrm{W}_{\mathrm{l}}$ : weight of lyophilized sample $(\mathrm{g})$

$\mathrm{W}_{\mathrm{o}}$ : weight of fresh sample $(\mathrm{g})$

The maximum force $(\mathrm{N})$ was determined using a TA.XT Plus Texture Analyser (Stable Micro Systems Ltd, Aname S.L, England), all the samples being cut perpendicularly to the muscle fibre direction at a crosshead speed of $10 \mathrm{~mm} / \mathrm{s}$. Prior to 
the analysis, samples were packaged in impermeable plastic bags and introduced in a water bath (P Selecta, Precisterm, Barcelona, Spain) at $80 \pm 1{ }^{\circ} \mathrm{C}$ for $2 \mathrm{~min}$.

The measurement of meat colour was studied by means of a Minolta Chrome Meter CM-2500d (Minolta Co. Ltd. Osaka, Japan), using CIELAB colour space (CIE, 1976) with the D65 Standard illuminate and the $10^{\circ}$ Standard Observer. The colour was expressed as the colour coordinates $\mathrm{L}^{*}$ (lightness), $\mathrm{a}^{*}$ (redness), and $\mathrm{b}^{*}$ (yellowness).

\subsubsection{Microbiological analyses}

The total aerobic mesophilic bacteria (TAMB) lactic acid bacteria (LAB), Escherichia coli and Salmonella spp. were determined in frozen, only freeze-dried and combined treated samples after $0,2,4,6$ and 8 months of storage. $25 \mathrm{~g}$ of chicken breast samples from each treatment were previously weighed, transferred to a sterile bag with $225 \mathrm{ml}$ sterile peptone water (Oxoid, CM0009, Hampshire, UK), and homogenised for 30 min using a stomacher (Stomacher 400 Circulator Seward, Colworth, UK). For each sample, appropriate serial decimal dilutions were prepared in the same sterile peptone water solution. Duplicate plates were made for each dilution. TAMB were determined according to ISO norm 4833 (05/2003), by using Plate Count Agar (PCA) (Biomérieux, Marcy-l'Etoile, France) after incubation at $35 \pm 1^{\circ} \mathrm{C}$ for $48 \pm 2 \mathrm{~h}$. LAB were determined according to the technique ISO 15214 (1998) on Man, Rogosa and Sharpe agar (MRS, Oxoid, UK), incubated at $30{ }^{\circ} \mathrm{C}$ during 3 days. Catalase test was done on presumptive lactic acid bacteria. E. coli was determined according to the ISO 16140 (ISO, 2003) and was incubated at $44 \pm 1{ }^{\circ} \mathrm{C}$ for $18-24 \mathrm{~h}$ by using Coli ID (Biomérieux, Marcy-l'Etoile, France). Salmonella was detected qualitatively (presence or absence) by the Enzyme Linked Fluorescent Assay (ELFA) performed by the mini-VIDAS instrument system (bioMerieux, Marcy l'Etoile, France). A pre-enrichment process was performed in broth buffered peptone water (BPW CM1049, Oxoid) for plate incubation at $37 \pm 1{ }^{\circ} \mathrm{C}$ for $24-26 \mathrm{~h}$. After incubation periods, the procedure DIN 10121 (2000) was followed. Thus, $0.1 \mathrm{ml}$ of pre-enriched samples was introduced into $10 \mathrm{ml}$ of Xylose Lysine Deoxycholate Agar plates (XLD-agar, bioMerieux, Marcy l'Etoile, France) and incubated at $41.5 \pm 1{ }^{\circ} \mathrm{C}$ for 24-26 h. After incubation, 1-2 $\mathrm{ml}$ of each XLD broth culture were combined and heated in a boiling water bath at $95-100{ }^{\circ} \mathrm{C}$ for $15 \pm 1 \mathrm{~min}$. After being cooled down to room temperature, $0.5 \mathrm{ml}$ was transferred into a Vidas Salmonella strip (SLM), which was analysed in the mini-VIDAS. Results were available after 45 min. Suspicious Salmonella colonies were inoculated onto XLD-agar, incubated at $37 \pm$ 
$1{ }^{\circ} \mathrm{C}$ for $24 \mathrm{~h}$ and then biochemically and serologically identified using Salmonella Latex test (Oxoid, Basingstoke, UK). All microbiological tests were carried out in duplicate, and the results expressed as $\log \mathrm{cfu} / \mathrm{g}$.

\subsubsection{Descriptive sensory analyses}

The descriptive sensory evaluation was performed by 5 trained panellists and the method of Hunt et al. (1991) was adopted to describe the sensory characteristics of the rehydrated treated chicken meat in five attributes: appearance, percentage of surface discoloration, chicken odour, odour characteristics and overall impression. Samples were evaluated for each attribute using a 7-point scale, in which 1 indicates the lowest score and 7 represents the highest score. For the evaluation of the texture profile attributes (TPA), the panel evaluated the rehydrated-cooked treated chicken meat for the three following sensory attributes: hardness, juiciness and chewiness (Lyon \& Lyon, 1990). Each attribute was rated on a seven-point scale, with a score 1 equivalent to the lowest intensity of the attribute and the score 7 to the highest intensity of the attribute. In both evaluations, visual and TPA, the limit of acceptability was 4 .

\subsection{Statistical analyses}

The analyses of variance (ANOVA) were carried out using the statistical package SPSS 11.0 software (SPSS Inc. Chicago, IL, USA). Pearson's correlation analyses and mean comparison were analysed according to Tukey's test, the significance being assigned at $P<0.05$ level.

\section{Results and discussion}

Firstly, a characterization of raw meat and all treated meat samples was carried out during the first day of storage. Secondly, the shelf-life of treated meat was studied during months $0,2,4,6$ and 8 .

\subsection{Physical and chemical characteristics of chicken breast meat under different combined treatments}

The values of $\mathrm{pH}$, water activity $\left(\mathrm{a}_{\mathrm{w}}\right)$, humidity $(\%)$, rehydration $(\%)$, and texture $(\mathrm{N})$ of treated and untreated meat samples are presented in Table 4.2. The mean $\mathrm{pH}$ was $5.88 \pm 0.21$ for fresh meat and $6.05 \pm 0.15$ for freeze-dried meat (trt- 0 ). The combination of ozone and lyophilisation reduced slightly the $\mathrm{pH}$ values in almost all combined 
treated samples, but the differences were statistically significant $(P<0.05)$ only between the treated samples at $0.6 \mathrm{ppm}$ of ozone for $10 \mathrm{~min}(\operatorname{trt}-0.6 / 10)$ and the untreated samples (trt-0). Similarly, Clavijo (2005) reported lower $\mathrm{pH}$ values for ozonated dried chicken breast fillets, as compared to control (non-ozonated dried) chicken breast fillets. This decrease of $\mathrm{pH}$ in combined treatment tends to inhibit microbial growth and survival (Stivarius et al., 2002). Alonso-Calleja, Martínez-Fernández, Prieto, and Capita (2004) found a high positive correlation between $\mathrm{pH}$ and microbial counts, indicating that high $\mathrm{pH}$ values favorably influences microbial growth.

However, water activity and humidity may be considered the most important factors in predicting the survival of microorganisms in food due to their direct influence on product quality and stability. The initial $\mathrm{a}_{\mathrm{w}}$ and moisture content of fresh chicken meat were about $0.984 \pm 0.002$ and $73.88 \pm 0.06 \%$, respectively. After lyophilisation, a significant decrease $(P<0.05)$ in those values was observed for the samples treated with lyophilisation (trt- 0$)\left(0.131 \pm 0.002\right.$ for $\mathrm{a}_{\mathrm{w}}$ and $2.93 \pm 0.06 \%$ for humidity). The significant decrease in levels of $\mathrm{a}_{\mathrm{w}}$ and humidity in meat during lyophilisation might inhibit microorganisms' growth in meat. Likewise, the reduction of $\mathrm{a}_{\mathrm{w}}$ and humidity values were similar to those found by Babić et al. (2009) in freeze-dried chicken meat with the same lyophilisation conditions.

For the samples with combined treatment (ozone and lyophilisation), $a_{w}$ values were significantly affected by both factors concentration of ozone and its time of exposure. Those values increased significantly $(P<0.05)$ when ozone concentration and exposure time increased. The water activity $\left(\mathrm{a}_{\mathrm{w}}\right)$ of the combined samples ranged between $0.162 \pm 0.005$ and $0.268 \pm 0.009$. It is important to note that all samples had $a_{w}$ values lower than 0.6. This value is considered as the limit of growth for microorganisms in food (Leistner, 1992), as all bacterial species fail to grow at $\mathrm{a}_{\mathrm{w}}$ of less than 0.6 (Barreiro \& Sandoval, 2006). Nevertheless, the moisture content increased when contact time of ozone increased, but it was found not to be significantly influenced by ozone concentration. Thus, samples from treatment trt-0.4/120 were noted to have a higher $(P<0.05)$ moisture content than samples from treatments trt- $0.4 / 60$ and trt- $0.6 / 30$. No significant differences were observed in samples that were ozonated for 10 and $30 \mathrm{~min}$.

On other hand, the mean rehydration percentage for the freeze-dried samples (trt-0) was $72.88 \pm 1.28 \%$. These results were similar to those reported by Babić et al. (2009) 
who found the highest rehydration percentages of $74.45 \pm 8.95 \%$ in freeze-dried Broiler chicken meat.

In the case of combined treated samples, the contact time of ozone had a significant effect on the percentage of rehydration $(P<0.05)$, and no significant effect was observed for ozone concentration. Our study suggests that the use of longer exposure time of ozone above $30 \mathrm{~min}$ caused significant decrease $(P<0.05)$ of the percentages of rehydration of the samples for both treatments (trt-0.4/60 and trt-0.4/120). These percentages were around $50 \%$, such products not having economic interest, as half of the product is not suitable to be eaten after rehydration. On the contrary, $30 \mathrm{~min}$ ozonation or less did not affect the percentages of rehydration.

Table 2. Determination for $\mathrm{pH}$, aw, humidity (\%), percentages of rehydratation (\%) and maximum force values $(\mathrm{N})$ for different treatments in chicken meat fillets

\begin{tabular}{|c|c|c|c|c|c|}
\hline Treatments & $\mathrm{pH}$ & Aw & Humidity $(\%)$ & $\begin{array}{c}\text { Rehydratation } \\
(\%)\end{array}$ & Texture $(\mathrm{N})$ \\
\hline \multicolumn{6}{|l|}{ Controls } \\
\hline Fresh meat & $5.88 \pm 0.21$ & $0.984 \pm 0.002$ & $73.88 \pm 0.06$ & - & $30.42 \pm 1.41$ \\
\hline trt-0 & $6.05 \pm 0.15^{y}$ & $0.131 \pm 0.002^{\mathrm{x}}$ & $2.93 \pm 0.06^{\mathrm{x}}$ & $72.88 \pm 1.28^{\mathrm{x}}$ & $40.05 \pm 0.93^{\mathrm{x}}$ \\
\hline \multicolumn{6}{|c|}{ Combined treatments: freeze-drying and ozonization (trt- $\left[\mathrm{O}_{3}\right]$ in ppm/time of exposure in minutes) } \\
\hline trt-0.4/30 & $6.04 \pm 0.09^{\text {Aay }}$ & $0.162 \pm 0.005^{\text {Aay }}$ & $2.93 \pm 0.08^{\operatorname{Aax}}$ & $75.03 \pm 1.76^{\mathrm{Cax}}$ & $40.91 \pm 0.53^{\text {Aax }}$ \\
\hline $\operatorname{trt}-0.4 / 60$ & $6.10 \pm 0.08^{\mathrm{Ay}}$ & $0.219 \pm 0.007^{\text {By }}$ & $3.78 \pm 0.10^{\mathrm{By}}$ & $52.66 \pm 1.52^{\text {Ву }}$ & $93.22 \pm 0.70^{\text {By }}$ \\
\hline trt- $0.4 / 120$ & $5.97 \pm 0.06^{\mathrm{Ay}}$ & $0.238 \pm 0.002^{\mathrm{Cy}}$ & $8.29 \pm 0.19^{\mathrm{Cy}}$ & $45.20 \pm 0.81^{\mathrm{Ay}}$ & $138.60 \pm 2.09^{\mathrm{Cy}}$ \\
\hline $\operatorname{trt}-0.6 / 10$ & $5.81 \pm 0.03^{\operatorname{Aax}}$ & $0.189 \pm 0.003^{\text {Aay }}$ & $2.96 \pm 0.03^{\operatorname{Aax}}$ & $73.26 \pm 1.97^{\operatorname{Aax}}$ & $41.15 \pm 0.87^{\operatorname{Aax}}$ \\
\hline $\operatorname{trt}-0.6 / 30$ & $6.10 \pm 0.05^{\text {Bay }}$ & $0.268 \pm 0.009^{\text {Bcy }}$ & $2.93 \pm 0.04^{\mathrm{Aax}}$ & $74.16 \pm 1.41^{\mathrm{Aax}}$ & $39.67 \pm 0.81^{\text {Aax }}$ \\
\hline $\operatorname{trt}-0.72 / 10$ & $5.95 \pm 0.09^{\mathrm{Aby}}$ & $0.216 \pm 0.005^{\text {Bby }}$ & $2.97 \pm 0.08^{\mathrm{Aax}}$ & $71.65 \pm 1.30^{\operatorname{Aax}}$ & $39.85 \pm 0.82^{\operatorname{Aax}}$ \\
\hline trt- $0.72 / 30$ & $6.10 \pm 0.06^{\text {Aay }}$ & $0.204 \pm 0.003^{\text {Aby }}$ & $2.96 \pm 0.07^{\text {Aax }}$ & $74.27 \pm 1.45^{\text {Aax }}$ & $40.97 \pm 0.18^{\operatorname{Aax}}$ \\
\hline
\end{tabular}

Data are expressed as means \pm standard deviation $(\mathrm{n}=10)$; Trt- 0 (freeze-dried meat, no treated with ozone)

A,B,C Different capital letters in the same column indicate that means are significantly different $(P<0.05)$ between samples treated with different exposure time of ozone

a,b,c Different lowercase letters in the same column indicate that means are significantly different $(P<0.05)$ between samples treated with different concentration of ozone

x,y Different letters in the same column indicate that means are significantly different $(P<0.05)$ between combined samples and freeze-dried samples.

Likewise, the maximum force was measured to indicate the force required to compress the meat. The maximum force value was approximately $30.42 \pm 1.41 \mathrm{~N}$ for fresh chicken meat, whereas a significant increase in the force value was observed in the freeze-dried meat (trt-0) 40.05 \pm 0.93 N. Similar results were reported by Babíc et al. (2009), who observed an increase in maximum force values for freeze-dried chicken meat when compared with those of fresh meat. The high values of maximum force $(\mathrm{N})$ 
reported for freeze-dried meats are probably explained by the application of slow freezing. Ciurzyńska and Lenart (2011) justified the change of texture and the final morphological characteristics of freeze-dried products by the growth of the ice crystals formed during slow-freezing process.

In the case of treated samples with ozone and lyophilisation, no significant differences $(P>0.05)$ were found among maximum force values at different concentration levels of ozone. However, the maximum force values were significantly $(P<0.05)$ increased by exposure time, when samples were exposed for a longer time (>30 min) in the treated samples (trt-0.4/60 and trt-0.4/120) compared with the control ones (trt-0). Nevertheless, there were no significant differences between the control (trt$0)$ and the rest of treated samples. A negative correlation $(\mathrm{r}=-0.865 ; P<0.01)$ between maximum forces and percentage of rehydration was observed, which indicates that when rehydration percentage decreased, maximum force values increased. These results suggest that the increase in maximum forces values of the samples (trt- $0.4 / 60$ and trt0.4/120) may be caused by the lower percentages of rehydration of those samples. Based on these results, the significant decrease in percentages of rehydration and the increase in maximum force values after 60 and 120 min exposure to $\mathrm{O}_{3}$ imply that ozonation time should be limited to less than $30 \mathrm{~min}$.

Related to changes in color, lightness $\left(\mathrm{L}^{*}\right)$, redness $\left(\mathrm{a}^{*}\right)$ and yellowness $\left(\mathrm{b}^{*}\right)$ values are presented in Table 4.3. The mean $\mathrm{L}^{*}, \mathrm{a}^{*}$ and $\mathrm{b}^{*}$ values of the fresh meat were $43.92 \pm 1.85,2.11 \pm 0.09,6.32 \pm 0.21$, respectively. Lyophilisation caused a significant increase $(P<0.05)$ in $\mathrm{L}^{*}(62.45 \pm 0.16)$, $\mathrm{a}^{*}(2.47 \pm 0.06)$ and $\mathrm{b}^{*}(13.91 \pm 0.05)$ values. In previous studies, an increase in $\mathrm{L}^{*}, \mathrm{a}^{*}$ and $\mathrm{b}^{*}$ values of freeze-dried meat was observed when compared to raw meat (Babić et al., 2009; Bengtsson \& Bengtsson, 1968). The combination of ozone with lyophilisation caused slighter increase in the $\mathrm{L}^{*}$ and $\mathrm{b}^{*}$ values in most treated samples compared with the non-ozonated control samples (trt- 0$)$. Our findings are not in agreement with those of Clavijo (2005), who reported a decrease in L* values in ozonated partially-dehydrated chicken meat. Muhlisin et al. (2015) also observed that exposure to gaseous ozone during 3-day storage did not affect $\mathrm{L}^{*}$ and $\mathrm{b}^{*}$ values of chicken breast meat. 
Table 3. Color parameters ( $L^{*}, a^{*}$ and $\left.b^{*}\right)$ of different treatments in chicken meat fillets

\begin{tabular}{|c|c|c|c|}
\hline Treatments & $\mathrm{L}^{*}$ & $a^{*}$ & $\mathrm{~b}^{*}$ \\
\hline \multicolumn{4}{|l|}{ Controls } \\
\hline Fresh meat & $43.92 \pm 1.85$ & $2.11 \pm 0.09$ & $6.32 \pm 0.21$ \\
\hline $\operatorname{trt}-0$ & $62.45 \pm 0.16^{\mathrm{x}}$ & $2.47 \pm 0.06^{\mathrm{x}}$ & $13.91 \pm 0.05^{\mathrm{x}}$ \\
\hline \multicolumn{4}{|c|}{$\begin{array}{l}\text { Combined treatments: freeze-drying and ozonization (trt- }\left[\mathrm{O}_{3}\right] \text { in } \mathrm{ppm} / \mathrm{time} \text { of exposure in } \\
\text { minutes) }\end{array}$} \\
\hline trt-0.4/30 & $63.36 \pm 1.09^{\text {Aax }}$ & $2.24 \pm 0.08^{\text {Bay }}$ & $14.47 \pm 0.43^{\text {Aax }}$ \\
\hline $\operatorname{trt}-0.4 / 60$ & $63.50 \pm 0.74^{\mathrm{Ax}}$ & $2.03 \pm 0.03^{\mathrm{Ay}}$ & $15.24 \pm 0.18^{\mathrm{By}}$ \\
\hline $\operatorname{trt}-0.4 / 120$ & $62.91 \pm 0.15^{\mathrm{Ax}}$ & $2.43 \pm 0.01^{\mathrm{Cx}}$ & $13.99 \pm 0.17^{\mathrm{Ax}}$ \\
\hline trt-0.6/10 & $66.51 \pm 0.21^{\text {Aay }}$ & $2.55 \pm 0.09^{\mathrm{Aax}}$ & $13.97 \pm 0.23^{\operatorname{Aax}}$ \\
\hline trt- $0.6 / 30$ & $66.69 \pm 0.55^{\text {Aby }}$ & $2.56 \pm 0.07^{\mathrm{Abx}}$ & $14.62 \pm 0.37^{\text {Aay }}$ \\
\hline Trt- $0.72 / 10$ & $68.18 \pm 0.22^{\text {Bby }}$ & $2.79 \pm 0.06^{\mathrm{Bby}}$ & $15.36 \pm 0.39^{\mathrm{Bby}}$ \\
\hline trt- $0.72 / 30$ & $66.38 \pm 0.41^{\text {Aby }}$ & $2.34 \pm 0.07^{\text {Aax }}$ & $14.41 \pm 0.19^{\operatorname{Aax}}$ \\
\hline \multicolumn{4}{|c|}{ Data are expressed as means \pm standard deviation $(\mathrm{n}=10) ;$ Trt- 0 (freeze-dried meat, no treated with ozone) } \\
\hline \multicolumn{4}{|c|}{$\begin{array}{l}\mathrm{A}, \mathrm{B}, \mathrm{C} \text { Different capital letters in the same column indicate that means are significantly different }(P<0.05) \text { betweer } \\
\text { samples treated with different exposure time of ozone }\end{array}$} \\
\hline \multicolumn{4}{|c|}{$\begin{array}{l}\text { a,b, Different lowercase letters in the same column indicate that means are significantly different }(P<0.05) \text { between } \\
\text { samples treated with different ozone concentrations }\end{array}$} \\
\hline
\end{tabular}

\subsection{Shelf-life and sensory quality}

\subsubsection{Microbiological analyses}

Changes in microbial populations (TAMB, LAB, and E.coli) for frozen chicken meat (FM), freeze-dried (trt-0) and combined treated meat are shown in Table 4.4 throughout eight months of storage. The initial load of the TAMB of the frozen chicken fillets (FM) was about $4.57 \log \mathrm{cfu} / \mathrm{g}$ in the first month of storage. These counts began to increase in those samples from the $2^{\text {nd }}$ month of storage and exceeded the estimated microbial limit of acceptability (7 log cfu/g) for poultry meat (EC Regulation No. 2073/2005 amended by EC regulation 1086/2011) at the end of storage (7.88 log cfu/g). Whereas, freezedried (trt-0) and combined treated samples did not reach this value during the 8 months of storage period (TAMB counts were always less than $5 \log$ units), a significant decrease $(P<0.05)$ of mesophilic bacteria counts was observed during storage time for freeze-dried samples (trt- 0 ) from the second month of storage onwards. The highest reduction in the TAMB counts in those samples was observed in the $6^{\text {th }}$ month of storage, as the initial level of the counts dropped from $4.63 \mathrm{log} \mathrm{cfu} / \mathrm{g}$ (month 0 ) to 1.98 $\log \mathrm{cfu} / \mathrm{g}$ on month 6 . The combination of ozone and lyophilisation significantly reduced the total aerobic mesophilic bacteria compared with those treated only with 
lyophilisation (trt-0). This fact may be attributed to the antimicrobial effects of ozone to destroy wide bacterial populations in food (Guzel-Seydim, Greene, \& Seydim, 2004). A previous research work carried out by Wu and Doan (2005) showed that ozone (23.09 $\mathrm{mg} / \mathrm{L}$ ) applied for $8 \mathrm{~min}$ inactivated $99 \%$ of the aerobic bacteria loads on red meat. Muhlisin et al. (2015) reported a reduction about $1.01 \mathrm{log} \mathrm{cfu} / \mathrm{g}$ and $1.07 \mathrm{log} \mathrm{cfu} / \mathrm{g}$ in total aerobic and anaerobic bacterial counts, respectively for ozone-treated chicken breast compared to the non-treated samples. Nevertheless, the aerobic mesophilic counts decreased significantly with increase of ozone concentration and exposure time. High ozone concentration of $0.6 \mathrm{ppm}$ or more had a considerable effect to increase the bacterial kill. It is noteworthy that mesophilic counts were significantly lower $(P<0.05)$ in almost all months $(0,2,4$ and 8$)$ with samples treated at 0.6 and $0.72 \mathrm{ppm}$ ozone for $30 \mathrm{~min}$ (trt-0,6/30 and trt-0,72/30) compared with samples treated at $0.4 \mathrm{ppm}$ for $30 \mathrm{~min}$ $(\operatorname{trt}-0,4 / 30)$.

Moreover, a slight decreasing trend in mesophilic counts was observed when the time of ozonation increased. The number of total aerobic mesophilic bacteria in the treatments trt- $0.4 / 60$ and trt-0.4/120 was significantly lower $(P<0.05)$ than in samples treated during $30 \mathrm{~min}$ (trt-0.4/30). There were no significant differences between the mesophilic counts of the samples treated with 10 and $30 \mathrm{~min}$. Similar findings were reported by Stivarius et al. (2002), who indicated that the application of $1 \%$ ozonated water at $7.2{ }^{\circ} \mathrm{C}$ for 15 min diminished all bacterial types compared with those treated for $7 \mathrm{~min}$. At the end of storage, the mesophilic counts were significantly reduced until $6.8 \mathrm{log} \mathrm{cfu} / \mathrm{g}$ and $3.26 \mathrm{log} \mathrm{cfu} / \mathrm{g}$ in the ozone treated samples with respect to the control ones, i.e. frozen meat and freeze-dried meat (trt- 0$)$, respectively.

Table 4. Microbiological changes (log cfu/g) of treated and untreated samples during eight months of storage

\begin{tabular}{|c|c|c|c|c|c|}
\hline & Month 0 & Month 2 & Month 4 & Month 6 & Month 8 \\
\hline Treatments & \multicolumn{5}{|c|}{$\overline{\text { (A) Total aerobic mesophilic bacteria counts }}(\overline{\log c f u / g})$} \\
\hline$\overline{\mathrm{FM}}$ & $4,57 \pm 0.05$ & $6,26 \pm 0,00$ & $6,78 \pm 0,28$ & $7,19 \pm 0,25$ & $7,88 \pm 0,05$ \\
\hline trt-0 & $4,63 \pm 0.06$ & $3,03 \pm 0.06$ & $3,45 \pm 0.05$ & $1,98 \pm 0.03$ & $4,26 \pm 0.03$ \\
\hline $\operatorname{trt}-0.4 / 30$ & $4,69 \pm 0.00$ & $3,64 \pm 0.06$ & $3,72 \pm 0.12$ & $1,35 \pm 0.05$ & $3,65 \pm 0.05$ \\
\hline $\operatorname{trt}-0.4 / 60$ & $4,69 \pm 0.00$ & $3,10 \pm 0.09$ & $3,39 \pm 0.09$ & $1,00 \pm 0.00$ & $1,81 \pm 0.04$ \\
\hline $\operatorname{trt}-0.4 / 120$ & $4,18 \pm 0.11$ & $3,45 \pm 0.07$ & $3,40 \pm 0.02$ & $1,15 \pm 0.05$ & $1,00 \pm 0.00$ \\
\hline trt- $0.6 / 10$ & $4,63 \pm 0.06$ & $3,25 \pm 0.05$ & $2,15 \pm 0.10$ & $1,89 \pm 0.01$ & $3,65 \pm 0.04$ \\
\hline trt- $0.6 / 30$ & $4,56 \pm 0.10$ & $2,96 \pm 0.13$ & $3,06 \pm 0.20$ & $2,03 \pm 0.03$ & $3,71 \pm 0.14$ \\
\hline $\operatorname{trt}-0.72 / 10$ & $4,46 \pm 0.03$ & $2,90 \pm 0.09$ & $2,96 \pm 0.10$ & $2,02 \pm 0.04$ & $3,04 \pm 0.09$ \\
\hline $\operatorname{trt}-0.72 / 30$ & $4,09 \pm 0.10$ & $2,35 \pm 0.02$ & $2,76 \pm 0.04$ & $2,44 \pm 0.03$ & $2,61 \pm 0.00$ \\
\hline
\end{tabular}




\begin{tabular}{lccccc}
\hline \multicolumn{7}{c}{$($ B) Lactic acid counts $(\log c f u / g)$} \\
\hline FM & $3,80 \pm 0.14$ & $5,77 \pm 0.10$ & $5,38 \pm 0.00$ & $5,20 \pm 0.24$ & $5,30 \pm 0.25$ \\
$\operatorname{trt}-0$ & $4,00 \pm 0.12$ & $2,41 \pm 0.38$ & $<1$ & $<1$ & $<1$ \\
$\operatorname{trt}-0.4 / 30$ & $4,54 \pm 0.21$ & $2,78 \pm 0.05$ & $1,49 \pm 0.09$ & $<1$ & $<1$ \\
$\operatorname{trt}-0.4 / 60$ & $4,54 \pm 0.21$ & $2,71 \pm 0.02$ & $1,25 \pm 0.07$ & $<1$ & $<1$ \\
$\operatorname{trt}-0.4 / 120$ & $4,49 \pm 0.09$ & $2,86 \pm 0.03$ & $2,04 \pm 0.06$ & $<1$ & $<1$ \\
$\operatorname{trt}-0.6 / 10$ & $4,31 \pm 0.12$ & $2,51 \pm 0.05$ & $<1$ & $<1$ & $<1$ \\
$\operatorname{trt}-0.6 / 30$ & $4,34 \pm 0.12$ & $<1$ & $<1$ & $<1$ & $<1$ \\
$\operatorname{trt}-0.72 / 10$ & $3,82 \pm 0.08$ & $2,62 \pm 0.09$ & $1,16 \pm 0.09$ & $<1$ & $<1$ \\
$\operatorname{trt}-0.72 / 30$ & $4,26 \pm 0.12$ & $<1$ & $<1$ & $<1$ & $<1$ \\
\hline \multicolumn{7}{c}{ (C) E. coli counts $(\log c f u / g)$} & & & \\
\hline FM & $1,75 \pm 0.07$ & $2,44 \pm 0.06$ & $2,11 \pm 0.00$ & $2,09 \pm 0.07$ & $1,00 \pm 0.00$ \\
$\operatorname{trt}-0$ & $<1$ & $<1$ & $<1$ & $<1$ & $<1$ \\
$\operatorname{trt}-0.4 / 30$ & $<1$ & $<1$ & $<1$ & $<1$ & $<1$ \\
$\operatorname{trt}-0.4 / 60$ & $<1$ & $<1$ & $<1$ & $<1$ & $<1$ \\
$\operatorname{trt}-0.4 / 120$ & $<1$ & $<1$ & $<1$ & $<1$ & $<1$ \\
$\operatorname{trt}-0.6 / 10$ & $<1$ & $<1$ & $<1$ & $<1$ & $<1$ \\
$\operatorname{trt}-0.6 / 30$ & $<1$ & $<1$ & $<1$ & $<1$ & $<1$ \\
$\operatorname{trt}-0.72 / 10$ & $<1$ & $<1$ & $<1$ & $<1$ & $<1$ \\
$\operatorname{trt}-0.72 / 30$ & $<1$ & $<1$ & $<1$ & $<1$ & $<1$ \\
\hline Data are expressed as means & & $<1$ & &
\end{tabular}

Data are expressed as means \pm standard deviation $(\mathrm{n}=2)$

FM: frozen meat; Trt-0 (freeze-dried meat, no treated with ozone); Combined treatment: freeze-drying and ozonization (trt-[O3] in ppm/time of exposure in minutes)

However, the LAB counts in freeze-dried and combined treated samples were significantly $(P<0.05)$ higher at the beginning of storage (month 0$)$ than those for the untreated control samples (FM). From the $2^{\text {nd }}$ month of storage, the LAB counts were significantly reduced and reached values less than $1 \mathrm{log} \mathrm{cfu} / \mathrm{g}$ for combined treated samples (trt-0.6/30 and trt-0.72/30). These results show a strong antimicrobial effect of ozone, as also Kim, Yousef, \& Khadre (2003) recently noted. The same authors suggested that gaseous and aqueous ozone, at a low dose and with short contact time is effective against numerous bacteria. Furthermore, ozone concentration seemed to be more effective for the inhibition of LAB in meat samples than contact time. Samples treated with 0.6 and $0.72 \mathrm{ppm}$ of ozone for $30 \mathrm{~min}$ had lower LAB counts than those treated with $0.4 \mathrm{ppm}$ ozone for $30 \mathrm{~min}$. More than 4.77-log reduction of LAB counts was observed from the second month of storage in combined treated samples (trt-0.6/30 and trt-0.72/30) when compared with untreated meat samples (FM) and 1.41-log reduction respect to non-ozonated meat (trt-0). In agreement with the present findings, a previous research work performed in our laboratory also showed a positive effect of ozone when applied with partial dehydration, as the growth of LAB was retarded in Broiler chicken meat (Clavijo, 2005). Nevertheless, no significant differences $(P>0.05)$ 
were found between samples treated with 0.6 and $0.72 \mathrm{ppm} \mathrm{O}_{3}$ along the months of storage. With respect to E.coli counts, more than $0.75 \log$ units of E.coli were killed at time zero (month 0) in treated samples. Nevertheless, the microbial counts for both untreated and treated samples with ozone did not exceed the Spanish legal limits (EC Regulation No. 2073/2005 amended by EC regulation 1086/2011). Finally, Salmonella was not detected in any of the chicken samples.

\subsection{Sensory analyses}

The results of the visual attributes for appearance, percentage surface discoloration, chicken odour and overall impression corresponding to the different treated samples during storage are shown in Figure 4.1.a-d. Frozen chicken meat was significantly scored $(P<0.05)$ highly for appearance (Figure 4.1a) and percentage surface discoloration (Figure 4.1b) compared to other treated samples. The limit of acceptability for appearance was reached after 4 months for the freeze-dried meat (the score obtained was lower than 4), which means the end of its shelf-life. In contrast, all samples treated with ozone remained acceptable for the panellists until the end of the storage (month 8). Concerning the percentage of discoloration, panellists gave similar scores for all treated samples. Statistical analyses did not show significant differences $(P>0.05)$ between frozen meat and all treated samples from the $6^{\text {th }}$ month of storage and reached average percentages of 40-59\%. In previous studies, Stivarius et al. (2002) used the same scale and reported lower percentages of discoloration between 20 and 39\% in beef trimmings treated with ozone, compared to the results of our study.

Related to chicken odour (Figure 4.1c), frozen meat had the highest score $(P<0.05)$ of chicken odour in most of the months. At the end of storage, (months 6-8), samples treated with ozone concentration higher than $0.4 \mathrm{ppm}$ had lower odour alteration and kept an acceptable chicken odour after 8 months of storage. On the contrary, the limit of acceptability of odour was reached from the $4^{\text {th }}$ month for the non-ozonated freeze-dried and 0.4 ppm-ozonated samples. Regarding the odour characteristics (results not shown), samples treated with lyophilisation (trt-0) and also with ozone maintained a score of 7 during the whole storage period. However, in the case of frozen samples, a slight perceptible odour was detected from the sixth month of storage, maybe caused by their higher microbial load (i.e. total aerobic mesophilic bacteria). These results are in agreement with those of Manousaridis et al. (2005) who reported better scores for odour attributes of ozone-treated shucked mussels $\left(\mathrm{O}_{3} / 90 \mathrm{~min}\right)$ when compared with the 
control ones. Similarly, Stivarius et al. (2002) found that the use of ozone in ground beef production process can be effective for reducing microbial pathogens with minimal effects on odour characteristics.

Likewise, based on the overall acceptability (Fig 4.1d), a significant decrease $(P<0.05)$ in average scores was observed during storage for all treated samples. The combined use of ozone and lyophilisation resulted in better acceptability of samples during all months. However, the frozen (FM), the freeze-dried (trt-0) and the combined treated samples at $0.4 \mathrm{ppm}$ (trt-0.4/30 and trt-0.4/60) were not considered acceptable for panellists at the end of the storage period.
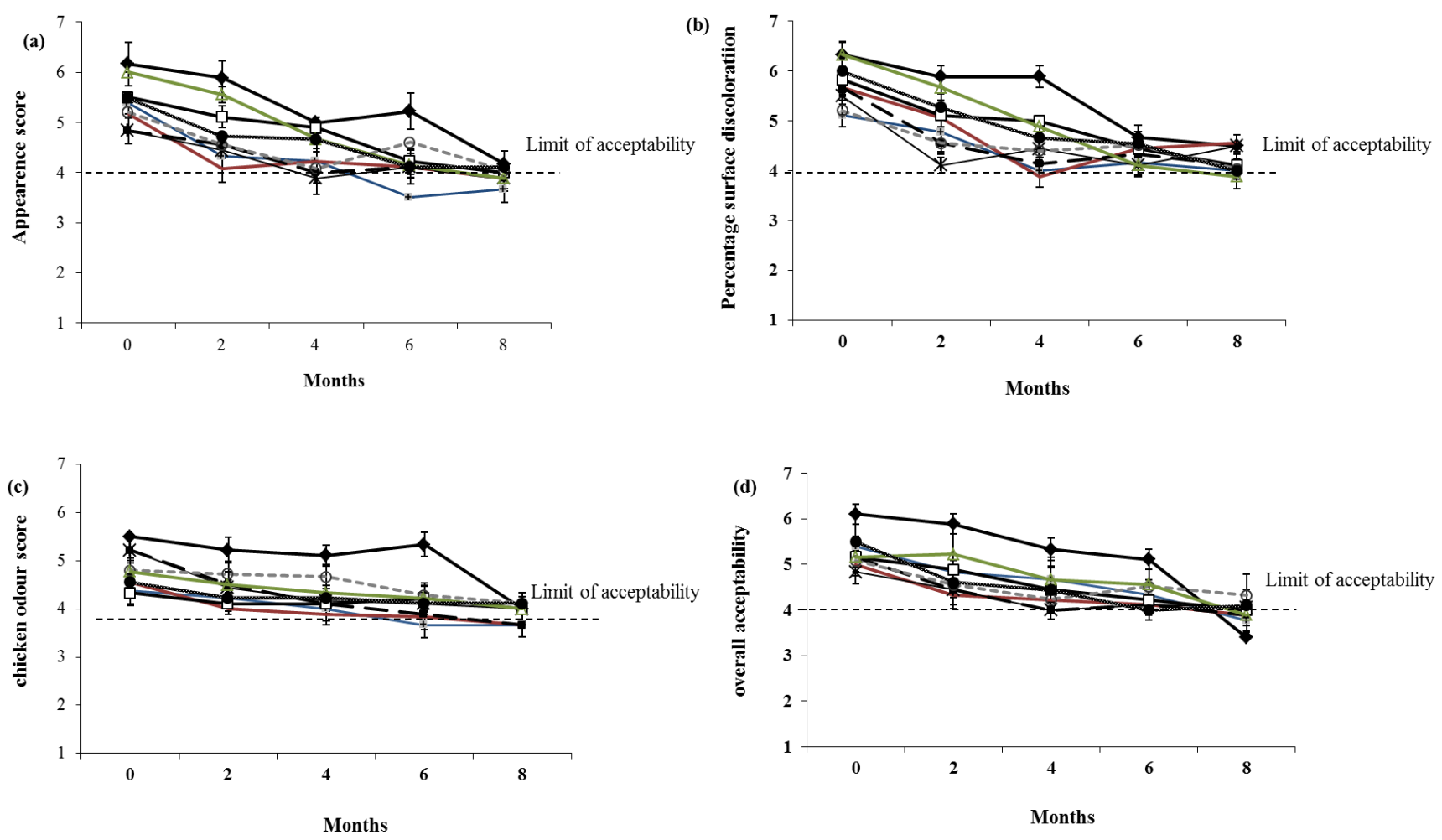

Figure 1. Changes in the visual attributes for appearance (a), percentage surface discoloration (b), chicken odour (c) and overall acceptability (d) of chicken freeze-dried meat treated with different time and concentration of ozone vs control (freeze-dried meat with no ozone) (trt- 0 ) and fresh meat (FM) during 8 months. Error bars represent standard deviation $(n=18)$. (4=limit of acceptability) 
The results of the texture profile attributes (hardness, juiciness and chewiness) evaluation of the different treated samples are presented in Figures. 4.2e-g. During the storage period, the hardness and chewiness scores of all samples decreased gradually. The samples treated with 60 and $120 \mathrm{~min}$ of ozone (trt- $0.4 / 60$ and trt- $0.4 / 120$ ) were considered unacceptable from the $2^{\text {nd }}$ month of storage (scored below 4 ), while samples of treatment trt-0.6/10 were above the limit of acceptability throughout the whole storage period. Our results suggest that the combination of ozone and lyophilisation was fairly successful in maintaining acceptable scores of hardness and chewiness up to 8 months of storage. The freeze-dried samples $(\operatorname{tr}-0)$ scored under the limit before month 6 of storage.
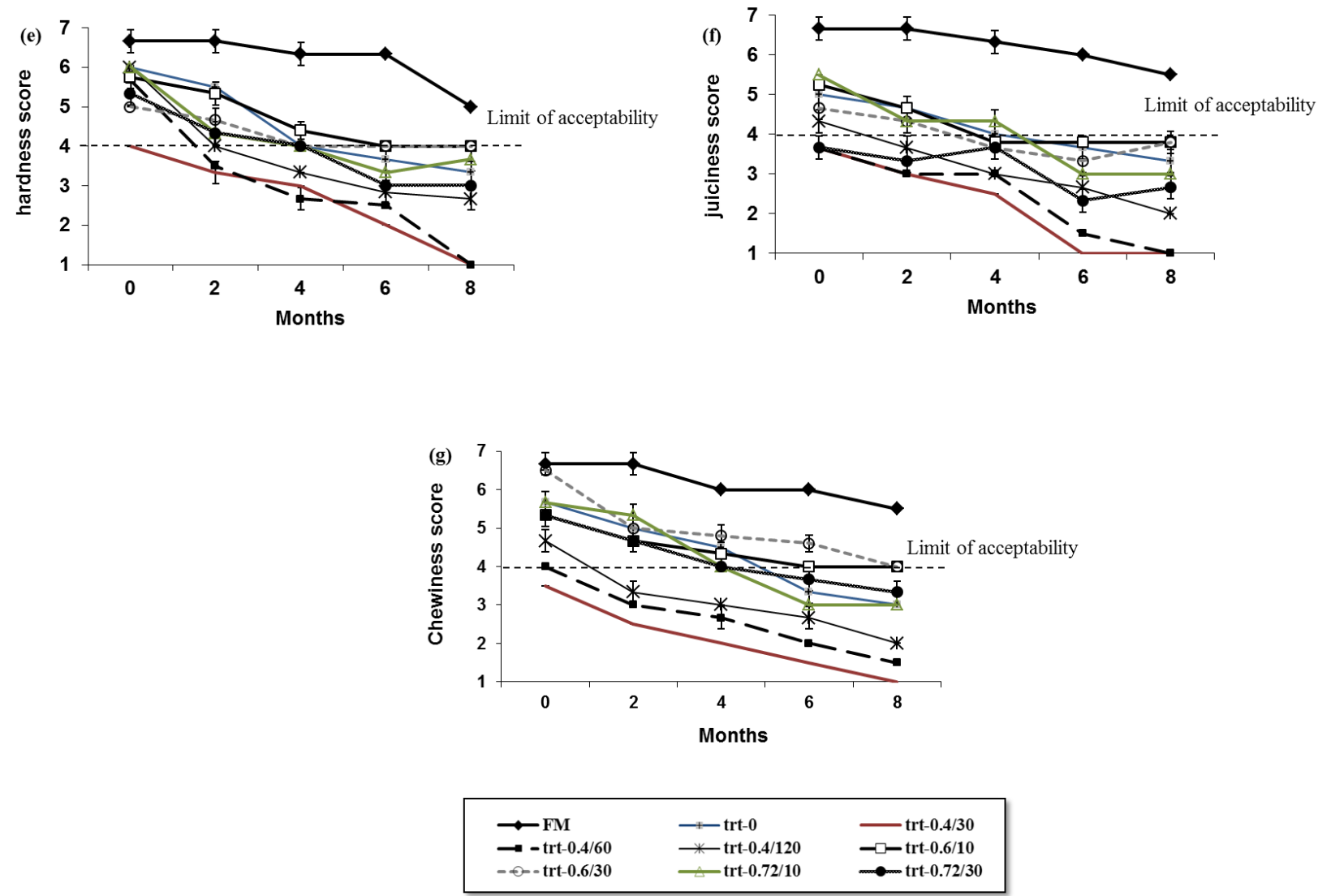

Figure 2. Changes in the texture profile attributes for hardness (e), juiciness (f) and chewiness $(\mathrm{g})$ of chicken freeze-dried meat treated with different time and concentration of ozone vs control (freeze-dried meat with no ozone) (trt-0) and fresh meat (FM) during 8 months. Error bars represent standard deviation $(n=18),(4=$ limit of acceptability) 
Relating to the juiciness attribute, frozen meat samples (FM) registered higher scores than the other treated samples throughout the months of storage, which indicated a moderately juicy meat (scores between 6.5 and 5.5) in the case of frozen samples. Also, samples of treatment trt-0.6/10 were acceptable throughout the whole storage period. On the contrary, the worst-scored samples were those treated with $0.4 \mathrm{ppm} \mathrm{O}_{3}$. Moreover, the scores for juiciness decreased significantly $(P<0.05)$ over the storage period in all treated samples. Lawrie (1998) suggests that the lyophilisation process determines some loss of juiciness in freeze-dried meat products. Furthermore, Casp and Abril (1999) reported that freeze-dried products stored in unfavourable conditions, are susceptible to all physical and chemical changes, as well as product oxidation which causes undesirable organoleptic characteristics. Therefore, a suitable packaging would be necessary for retaining the majority of their physical, chemical and sensorial proprieties of dried meats.

\section{Conclusions}

The combination of ozone ( $0.6 \mathrm{ppm}$ for $10 \mathrm{~min})$ and lyophilisation would be useful in enhancing the microbial properties of meat, in achieving a sensory acceptable product, as well as, in extending the shelf-life of raw chicken breast meat up to 8 months. On the contrary, the samples treated with lyophilisation alone had a shelf-life of only 4 months. Likewise, the $0.4 \mathrm{ppm}$ exposure to ozone had a negative effect on increasing both the hardness and chewiness of chicken meat. Further research work would be needed to determine the optimum conditions of modified atmosphere packaging (MAP) for maximizing the shelf-life extension of ozonated freeze-dried chicken meat.

\section{References}

Abdelwahed, W., Degobert, G., Stainmesse, S., \& Fessi, H. (2006). Freeze-drying of nanoparticles: Formulation, process and storage considerations. Advanced Drug Delivery Reviews, 58(15), 1688-1713.

Alonso-Calleja, C., Martínez-Fernández, B., Prieto, M., \& Capita, R. (2004). Microbiological quality of vacuum-packed retail ostrich meat in Spain. Food Microbiology,21(2),241-246 
Alzamora, S. M., Tapia, M. S., Argaíz, A., \& Welli, J. (1993). Application of combined methods technology in minimally processed fruits. Food Research International, 26 (2), 125-130.

AOAC. (1975). Official methods of analyses (12th ed.). Washington, D.C., USA.

Babić, J., Cantalejo, M. J., \& Arroqui, C. (2009). The effects of freeze-drying process parameters on Broiler chicken breast meat. LWT - Food Science and Technology, 42(8), 1325-1334.

Barreiro, M., \& Sandoval, B. (2006). Operaciones de conservación de alimentos por bajas temperaturas (1th Ed).Venezuela: Equinoccio.

Bengtsson, O., \& Bengtsson, N. (1968). Freeze-drying of raw beef. II. Influence of some freezing and deshydratation variables. Journal of the Science of Food and Agriculture, 19, 480-485.

Casp, A., \& Abril, J. (1999). Procesos de conservación de alimentos. (2th ed.). Madrid: Ediciones Mundi-Prensa.

Chang, C. H., Lin, H. Y., Chang, C. Y., \& Liu, Y. C. (2006). Comparisons on the antioxidant properties of fresh, freeze-dried and hot-air-dried tomatoes. Journal of Food Engineering, 77(3), 478-485.

CIE. (1976). International commission on illumination, colorimetry: Official recommendation of the international commission on illumination publication $\mathrm{CIE}$ No. (E- 1.31). Paris, France: Bureau Central de la CIE.

Ciurzyńska, A., \& Lenart, A. (2011). Freeze-Drying - Application in Food Processing and Biotechnology - A Review. Polish Journal of Food and Nutrition Sciences, 61(3), 165-171.

Clavijo, C. (2005). Development of a new raw meat product from Broiler chicken breast meat after ozonation, partial dehydration and vacuum packaging. $\mathrm{PhD}$ Thesis. Public University of Navarre, Pamplona, Spain (in Spanish).

European Commission Regulation (EU) No 1086/2011 of 27 October 2011, amending Annex II to Regulation (EC) No 2160/2003 of the European Parliament and of the Council and Annex I to Commission Regulation (EC) No 2073/2005 as regards Salmonella in fresh poultry meat.

De Barcellos, M. D., Kügler, J. O., Grunert, K. G., Van Wezemael, L., Pérez-Cueto, F. J. A., Ueland, Ø., \& Verbeke, W. (2010). European consumers' acceptance of beef processing technologies: A focus group study. Innovative Food Science and Emerging Technologies, 11(4), 721-732.

DIN 10121. (2000). Detection of Salmonella in foodstuffs by enzyme-linked fluorescent immunoassay. Beuth, Berlin, Germany. 
FAO. (2014). Food and Agriculture Organization of the United Nations. FISHSTAT. Global Aquaculture Production.

Guzel-Seydim, Z. B., Greene, A. K., \& Seydim, A. C. (2004). Use of ozone in the food industry. LWT - Food Science and Technology, 37 (4), 453-460.

Hammami, C., \& René, F. (1997). Determination of freeze-drying process variables for strawberries. Journal of Food Engineering, 32 (2), 133-154.

Hunt, M.C., Acton, J.C., Benedict, R.C., Calkins, C.R., Cornforth D.P., Jeremiah, L.E., Olson, D.G., Salm, C.P., Savell, J.W., \& Shivas, S.D. (1991). AMSA guidelines for meat color evaluation. In Proceedings $44^{\text {th }}$ Annual Reciprocal Meat Conference (pp. 3-17), 9-12 July 1991, Kansas State University, Manhattan, USA.

International Standards Organisation (ISO) (1973). Determination of total fat content, ISO 1443:1973 standard. In International standards meat and meat products. Genève, Switzerland: International Organization for Standardization.

International Standards Organisation (ISO) (1998). International Standard ISO 15214:1998 Microbiology of Food and Animal Feeding Stuffs. In Horizontal Method for Enumeration of Mesophilic Lactic Acid Bacteria. Colony Count Technique at $30^{\circ} \mathrm{C}$.

International Standards Organisation (ISO) (2003). ISO 16140:2003, Microbiology of food and animal feeding stuffs. Protocol for the validation of alternative methods.

Jayasena, D. D., Kim, H. J., Yong, H. I., Park, S., Kim, K., Choe, W., \& Jo, C. (2015). Flexible thin-layer dielectric barrier discharge plasma treatment of pork butt and beef loin: Effects on pathogen inactivation and meat-quality attributes. Food Microbiology, 46, 51-57.

Khadre, M. A., \& Yousef, A. E. (2001). Decontamination of a multilaminated aseptic food packaging material and stainless steel by ozone. Journal of Food Safety, 21, $1-13$.

Kim, J. G., Yousef, A. E., \& Khadre, M. A. (2003). Ozone and its current and future application in the food industry. Advances in Food and Nutrition Research, 45, $167-218$.

Kim, J., Yousef, A. E., \& Chism, G. W. (1999). Use of ozone to inactivate microorganisms on lattuce. Journal of Food Safety, 19 (1), 17-34.

Lawrie, R. . (1998). Lawrie's Meat Science (6th ed.). UK, Cambridge: Woodhead Publishing Ltd.

Leistner, L. (1992). Food preservation by combined methods. Food Research International, 25, 151-158. 
Litvin, S., Mannheim, C. H., \& Miltz, J. (1998). Dehydration of Carrots by a Combination of Freeze Drying, Microwave Heating and Air or Vacuum Drying. Journal of Food Engineering, 36, 103-111.

Lyon, B. G., \& Lyon, C. E. (1990). Texture Profile of Broiler Pectoralis major as Influenced by Post-Mortem Deboning Time and Heat Method. Poultry Science, 69 (2), 329-340.

Manousaridis, G., Nerantzaki, A., Paleologos, E. K., Tsiotsias, A., Savvaidis, I. N., \& Kontominas, M. G. (2005). Effect of ozone on microbial, chemical and sensory attributes of shucked mussels. Food Microbiology, 22 (1), 1-9.

Muhlisin, Cho, Y., Choi, J. H., Hahn, T.-W., \& Lee, S. K. (2015). Bacterial Counts and Oxidative Properties of Chicken Breast Inoculated with Salmonella Typhimurium Exposed to Gaseous Ozone. Journal of Food Safety, 35 (1), 137-144.

Sekhon, R. K., Schilling, M. W., Phillips, T. W., Aikins, R. M. J., Hasan, M. M., Nannapaneni, R., \& Mikel, W. B. (2010). Effects of carbon dioxide and ozone treatments on the volatile composition and sensory quality of dry-cured ham. Journal Food Science, 75 (5), 452-458.

Stivarius, M. R., Pohlman, F. W., McElyea, K. S., \& Apple, J. K. (2002). Microbial, instrumental color and sensory color and odor characteristics of ground beef produced from beef trimmings treated with ozone or chlorine dioxide. Meat Science, 60 (3), 299-305.

Turantaş, F., Kılıç, G. B., \& Kılıç, B. (2015). Ultrasound in the meat industry: General applications and decontamination efficiency. International Journal of Food Microbiology, 198, 59-69.

Van Wezemael, L., Verbeke, W., Kügler, J. O., de Barcellos, M. D., \& Grunert, K. G. (2010). European consumers and beef safety: Perceptions, expectations and uncertainty reduction strategies. Food Control, 21(6), 835-844. 